Max-Planck-Institut für demografische Forschung Max Planck Institute for Demographic Research Konrad-Zuse-Strasse 1 - D-18057 Rostock · GERMANY

Tel +49 (0) 3812081 - 0; Fax +49 (0) 3812081 - 202;

http://www.demogr.mpg.de

MPIDR WORKING PAPER WP 2004-023

AUGUST 2004

\title{
The Effects of Socio-Cultural and Labor Market Conditions on Marital Separation during the Early Democratic Period in Spain
}

René Houle (houle@ demogr.mpg.de)

This working paper has been approved for release by: Vladimir M. Shkolnikov (shkolnikov@ demogr.mpg.de), Head of the Laboratory for Demographic Data.

(C) Copyright is held by the authors.

Working papers of the Max Planck Institute for Demographic Research receive only limited review. Views or opinions expressed in working papers are attributable to the authors and do not necessarily reflect those of the Institute. 


\title{
The Effects of Socio-Cultural and Labor Market Conditions on Marital Separation during the Early Democratic Period in Spain
}

\author{
René Houle \\ Max-Planck Institute for Demographic Research, Rostock
}

July 2004

During the Spanish democratic transition of the late seventies and up into the eighties, many rapid changes occurred affecting family and women's status in the society: the progressive modernization and "internationalization" of the economy (especially the development of the service sector), the democratization of politics, the end of the paternalistic (if not repressive) system that clearly maintained women in an inferior position with respect to men, and many legislative changes. In late 1981, legislation on divorce was introduced. As a result, the number of separations and divorces began to rise, however at a slow pace, and, put in the European context, continued to do so until today. Even though the total divorce rate has grown constantly between 1983 and 1998, from 9 to 15.5 divorces per 100 marriages, it is far from reaching the level of other European countries such as Sweden (43\%) or France $(32 \%)^{1}$. On the other hand, the male breadwinner system is still prevailing within marriage and women's participation in the labor market remains low by European standards. Social welfare aimed at supporting families is almost non-existent and working parents have to rely on their family network or on the private sector for help in caring for their young children (aged below 3).

In this paper, we examine the socio-cultural conditions and labor market participation correlates of marital separation in transition Spain. The reason is that it

\footnotetext{
* I would like to thank Jan Hoem for his useful comments on this paper. I'm also indebted to my former colleagues in Barcelona, Montserrat Solsona, Rocío Treviño and Carles Simó, with whom I first began to work on this subject many years ago.

${ }^{1}$ Data for 1990. Source: Conseil de l'Europe (1997). For Spain in 1990, the indicator is 10.3\%. For 1995, we have the following figures: $53.9 \%$ in Sweden, 39\% in France and $14.4 \%$ in Spain (Monnier 1999 and Treviño et al. 2000).
} 
has been clearly shown that these factors are much more strongly related to divorce in Spain and other Mediterranean countries than in other parts of the Western world. In Spain, as in Italy, marital disruption is highly selective. Men and women who have completed secondary education at least and women who participate in the labor market are more prone to be involved in marital separation than other groups.

We focus our attention on differences between men and women and use some theoretical frameworks that explain divorce rates in industrialized countries. We especially include "modernization" in aiming to explain divorce in Spain during its early period of integration in contemporary Europe. One feature of this work is that "modernization" is captured not only on an individual but also on a contextual level. This dual approach is especially relevant in a country such as Spain, i.e. where regional heterogeneity in economic and socio-cultural spheres is large and the influence of the family and local community is still strong. The contextual units we retain are defined below.

This paper is divided into six sections. The following one gives some very brief elements of Spanish society during this period. The third section discusses some theoretical frameworks, starting with the "modernization" framework. The data and methodology are presented next. Main results and corresponding discussions are introduced in the fifth section, followed by a discussion of the results in the last section.

\section{Change and continuity}

Both change and continuity characterize Post-Franco Spain. After the death of the dictator and the collapse of the totalitarian regime, the country experimented social and economic changes that other Western societies saw one or two decades before. Suffice it to mention here the rapid increase of the service sector fueled by growing State spending on a new and needed welfare system, especially on education, health and old-age pensions (Baizán et al. 2002). This led to the creation of wider work opportunities for women since male unemployment was at its lowest level ever, i.e. below 4\%. This, in turn, translated into a rapid increase of labor market participation of married women, especially the youngest ones. In parallel, female presence in the educational system also increased significantly. 
Some of these changes were already visible a few years before Franco's death, but took on another significance with transition and could hardly be put to an end. The economic modernization of the country, for example, had already begun in the early sixties, mostly as a result of the development of industry and the construction sectors and at the expense of the agricultural sector. Until the seventies, Franco imposed a strict male-breadwinner / female-homemaker system, according to which married women had to take care of the home and the children while married men earned a living for the family, sometimes for long hours (it was not uncommon to have more than one job). Married women's participation in the labor market is clearly a distinct feature of the new political era (Figure 1) and the growing service sector constituted a strong incentive for their participation (Figure 2).

\section{Figure 1. Married women's labor force participation by age group}

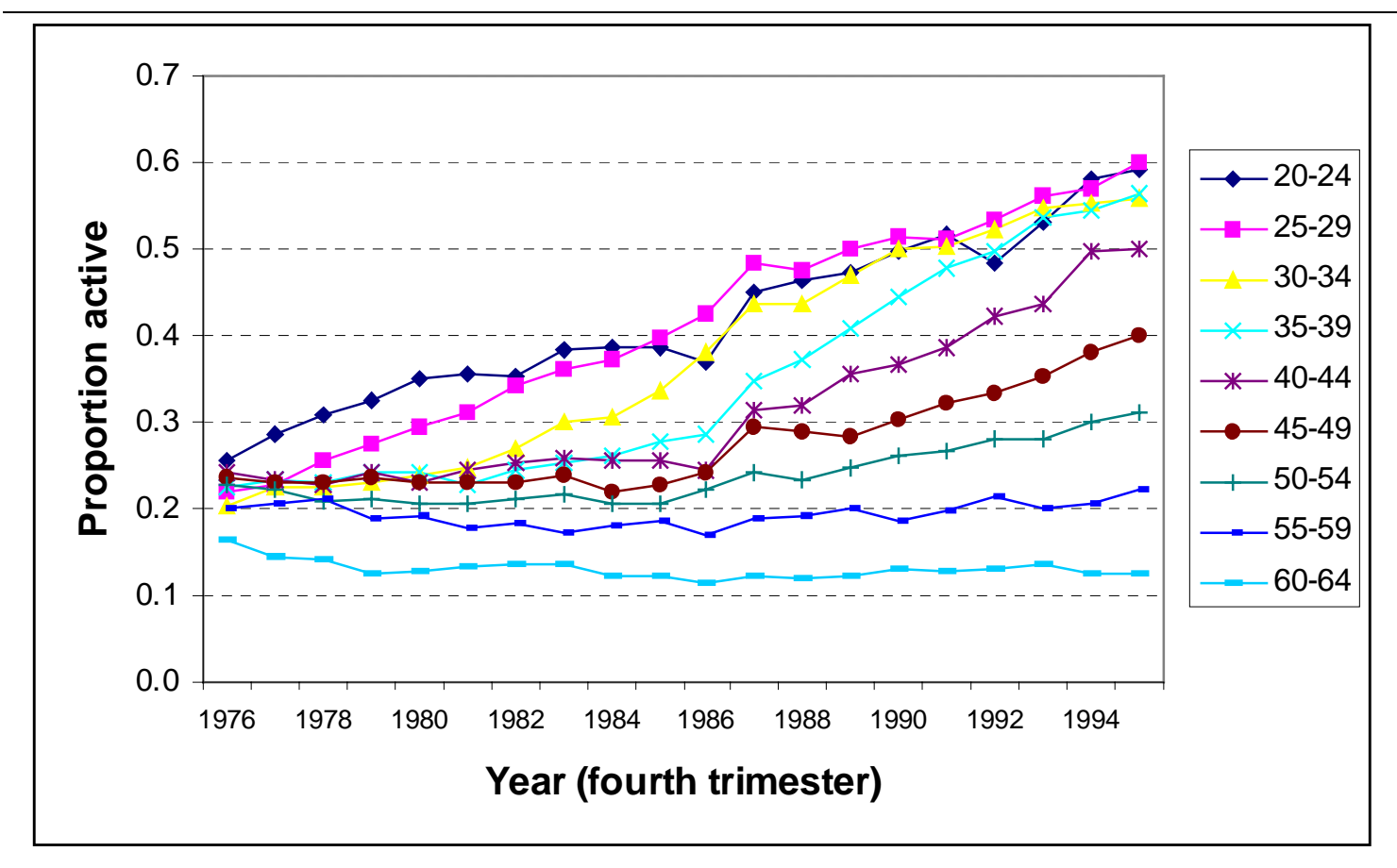

Source: INE, Labor Force Surveys (EPA). Annual data of fourth trimester. 

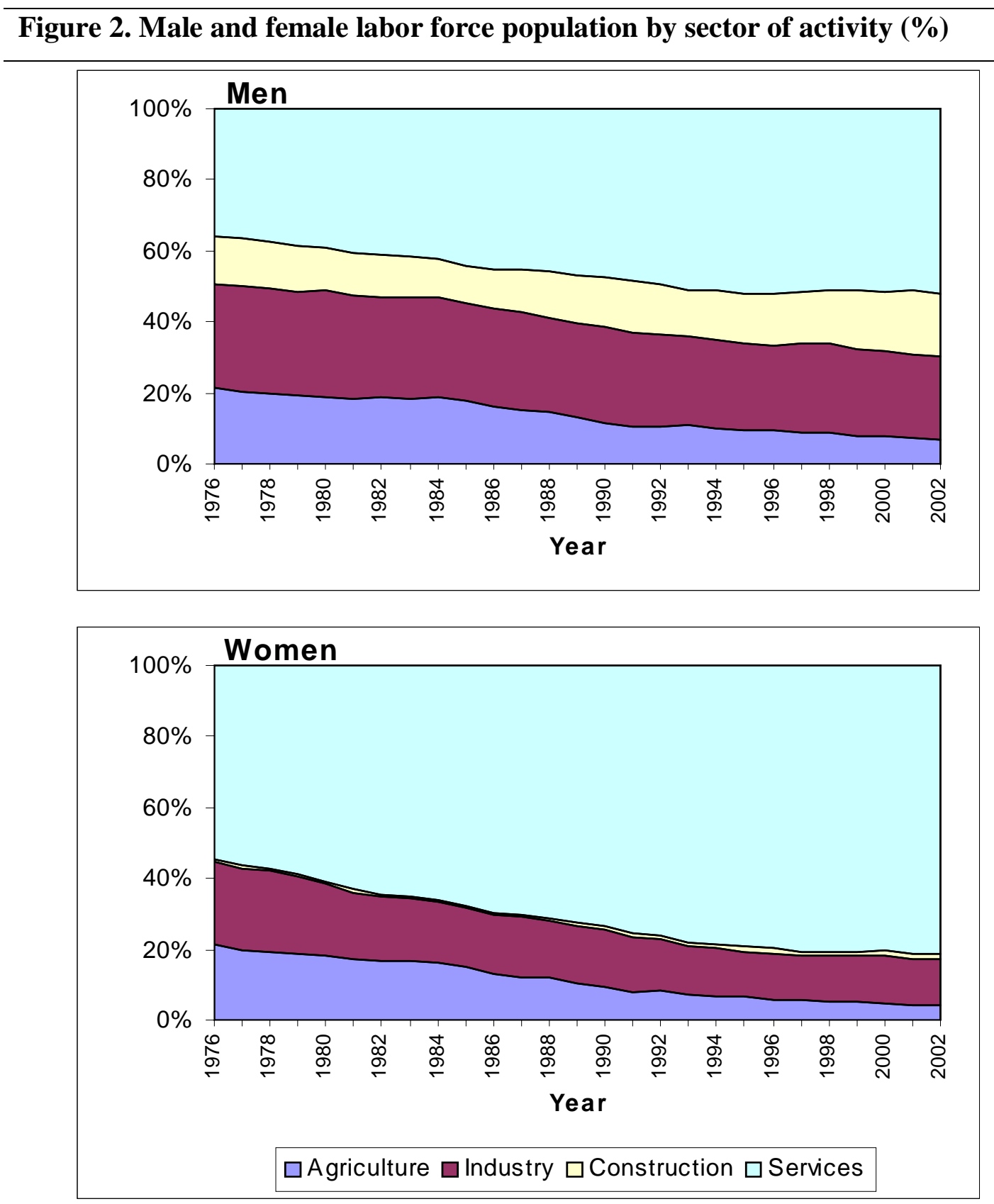

Source: Web of INE, Labor Force Surveys (EPA). Annual data of fourth trimester.

Other important changes occurred in the realm of legislation. The divorce law of 1981 was a first step towards greater popular acceptance of divorce in Spain (Figure 3). Naturally, during the late seventies and before its introduction many marriages dissolved (sometimes on the basis of a separation contract) ${ }^{2}$, but the law permitted greater process regulation, especially as to protecting the rights of children, 
and it facilitated a relatively high percentage of common agreement (comun acuerdo) separations. Many other interventions also affected the educational system, the labor market, the tax and welfare systems and, naturally, the political life (e.g. the 1976 Law of Political Reform, the legalization of the Communist Party in 1977, the adoption of the Constitution in 1978).

\section{Figure 3. Annual number of legal separations and divorces, and percentage of separations obtained by common agreement}

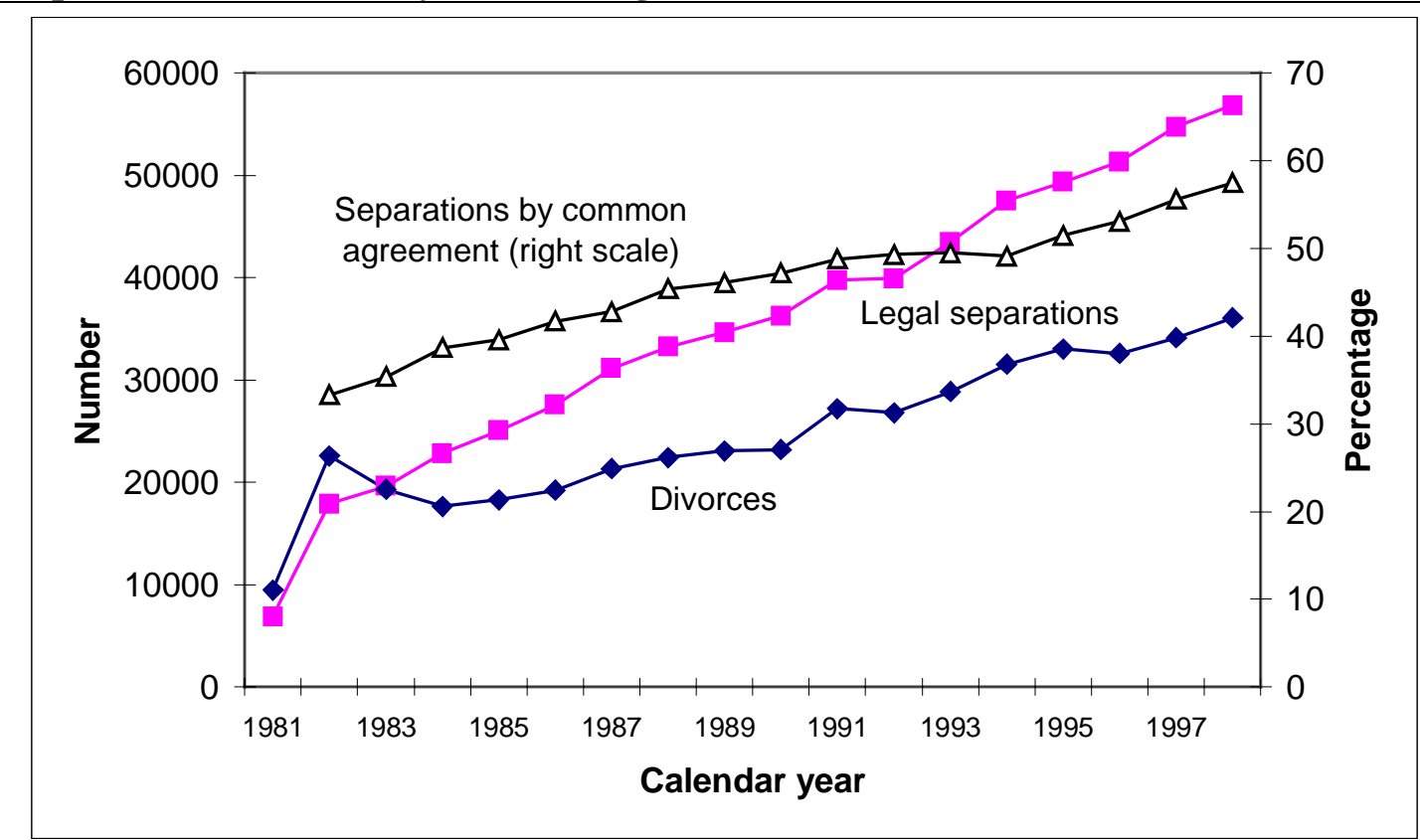

Source: Statistics of "Poder Judicial” General Council.

The transformations of the country's social and economic life took place in the background of continuity. Forty years of strong normative and political control could not be erased by the political and social transition. In part, continuity was the result of a slow replacement of older generations by youngest ones. Labor market participation of young married women increased rapidly from the seventies onwards; however, this was not the case for the oldest ones (over 40 years). In general, the family was an institution that kept many of its pre-transition features, and it is still considered a traditional form of family different from the rest of European ones (Reher 1977).

\footnotetext{
${ }^{2}$ During the Franco Era, it was almost impossible to have a regulated separation, unless the marriage was nullified by the Catholic Church.
} 
One of the characteristics of the new Spanish welfare system was its quasi non-interventionist attitude in family matters. The present welfare system protects those who have a stable job, while those who do not receive very little protection. Spain is one of the Western countries with the strongest labor rigidities (EspingAndersen 1999, Table 2.2) in Europe. Moreover, support for children and childcare services are not well developed (González et al. 1999). The Spanish family welfare system assumes that men are family breadwinners and women stay at home to care for the children, they are homemakers. It is a system based on family solidarity. As a result, there exists no support for divorcees and lone-parents (mostly women), which are hence penalized by their own unorthodox family situation. There have been recent changes, but for the period under study here (1977-1990), a woman who wanted to divorce had to think hard about it, especially if she has or had children. This means that some reasons behind continued low fertility in Mediterranean countries (EspingAndersen 1997, 1999) also account for low divorce rates.

\section{Theoretical perspectives}

In what way does the combination of rapid political and socioeconomic transformations on the one hand and the maintenance of basic family values and a "women-and-family-unfriendly" welfare system on the other impact divorce rates in Spain? No specific theory addresses this question directly; nevertheless many scientific studies provide some answers. In this review, we are particularly interested in the way in which education and employment of both husbands and wives are related to divorce, taking the perspective of the recent past.

The so-called "trading and specialization model" of marriage (Becker et al. 1977) explicitly aims at explaining divorce trends and correlates within the malebreadwinner context of the US. This model has received a great deal of criticism in the last few years (Oppenheimer 1994, 1997a) as it is not applicable to the more egalitarian model of marriage that prevails today. The model is based on the independence hypothesis. Briefly, and in the words of Oppenheimer (1997:432), it stipulates that "the major gain to marriage lies in the mutual dependence of spouses, arising out of their specialized functions - the woman in domestic production (and reproduction), the man in market work. Marriage than involves trading the fruits of 
these different skills". For divorce, this has come to mean that women's participation in the labor market (in terms of the number of hours worked and/or relative earnings) should be positively related to divorce as it undermines the original division of labor in the household. On the other hand, theory says that a high total income acts as a stabilizing factor in marriage by improving the quality of family life. In this view, an alternative consequence of women's work would be a decline in divorce risk, and this may be the case when the employment of wives is an adaptive family strategy aimed at increasing the economic well-being of the family, as it is presumably the case in a more "collaborative" (or egalitarian) model of marriage (Oppenheimer 1994). It follows from this that to be able to disentangle the independence effect from the adaptive effect of spouses' work on divorce in present Western societies, it is necessary to take into account in the analysis both spouses' relative income and family total income (Liu \& Vikat 2004). However, Spanish couples of the eighties hardly embraced the egalitarian model of marriage, and one may wonder to what extent the paid employment of Spanish wives during political transition can be considered an adaptive family strategy. Spouses' decision to work is motivated by other considerations, too, and we will address these below.

The view above also considers the effect on divorce of a change in the economic situation of men. Becker et al. (1977) argue that a deterioration in male earnings increases the risk of divorce. This is because it widens the "deviation between actual and expected earning". This argument is a direct result of the specialization model that assumes the man to be the main provider of income in the family. A deterioration of his income decreases a major gain to marriage for the wife, leading to a higher risk of divorce. Oppenheimer adopts a similar approach. Her argument is that "since the husband has typically been the source of most of the family's income, his labor-market position should have an important effect on marital stability" (Oppenheimer 1994: 442). In the analysis of the effect of men's economic position on divorce, the underlying type of marriage is the one where the husband earns a higher income than does his wife. Therefore, to some extent it is just another way of expressing the total income effect on marital dissolution.

In the classical version of the specialization model of marriage, "there is no clear theoretical prediction about the net effect of schooling level on the gain to 
marriage" (Becker et al. 1977: 1147). This is due to opposite effects of high education on gain to marriage. On the one hand, high education increases the gain to marriage because of high levels of market and non-market skills of spouses. On the other, it reduces the specialization of spouses, and thus the gain to marriage. Our understanding of these two propositions is, first, that higher education means a better situational placement of the husband in the labor market at the same time as it reduces the necessity for the wife to earn an income. Second, higher education also implies that an educated wife may have greater opportunities to participate in the labor market as their less educated counterparts. We will see later that the effect of education on divorce in Spain is positive for both men and women, which points to the necessity of having another theoretical framework to explain this relation.

The reason for the success of the independence hypothesis, at least in the USA, is probably related to the fact that many post baby-boom family transformations are closely related to the rise of women's employment ${ }^{3}$. However, as Cherlin points out (1992: 53), this may be only circumstantial - even though a suggestive - evidence. In the present work, the specialization model of marriage and the independence hypothesis have a definite relevance, since Spain in the period under study (19771990) remains a country in which marriage is still dominated by the malebreadwinner model.

Family change since the end of the sixties is not only affected by women's employment and other labor market considerations. Institutional change, ideational transformation and a sex-role revolution took place at different paces (Lesthaeghe 1983, Davis 1984, Goldscheider and Waite 1991). The value revolution in family and reproduction (known as the Second Demographic Transition in Europe - SDT) has made divorce and family arrangements outside formal marriage increasingly acceptable and set the basis for egalitarian marriage. The former division of labor in the household between husband and wife has progressively lost its ground and been replaced by a dual-earner couple model where the sharing of domestic tasks is more common. Fueled by economic change and the end of many normative controls on

\footnotetext{
${ }^{3}$ Cherlin (1992:53) writes that ".... it is possible to make three statements: (1) a married woman may be more likely to divorce if she is in the labor force; (2) the labor force participation rate for younger married women rose sharply after 1960; and (3) younger married women are in general more likely to divorce than older married women".
} 
family matters, Spain in the eighties experienced some SDT developments. However, it did not become a strong characteristic of Spanish demographic evolution during this period and the main family functioning continued to be based on the "traditional" specializing and trading model, as pointed out earlier. In any case, according to the SDT theory people with more secular, egalitarian and individualistic (less traditional) values than their counterparts face higher risks of divorce (as well as of cohabitation, pre-marital birth and to be found in non-conventional types of households in general). In a modernizing society such as Spain of the eighties, these new values were shared by the better educated.

Institutional change (divorce law, democratization of politics, economic reforms, mass education) was decisive in many aspects of Spanish society and led to an increase in divorce rates. The new welfare system did not intervene in family matters, and as a result new divorcees needed to have the capacity to ensure some economic security for themselves and their children in order to deal with the new situation. For women at least, having some sort of qualification was probably a first and desirable step to enter the growing service sector. Some authors have also pointed out that in a society in which social norms are still strong (as in Italy and Spain), especially regarding family life, education provides the intellectual capital necessary to defy these norms and to cope with the economic consequences (Blossfeld et al. 1995).

The positive relationship between education and divorce is not easy to establish on theoretical grounds, even though the association is well documented in the Mediterranean setting. The work of Blossfeld et al. suggests that as divorce and education are becoming more common, the positive effects of education and employment on divorce are progressively disappearing. This has been observed in Spain (Treviño et al. 2000) and even in Sweden where divorce is a common practice (Hoem 1977). A similar pattern was also found for women's employment and men's unemployment in Australia (Bracher et al. 1993). The tempo of this parallel evolution, however, may by slowed down by a very conservative welfare system: Having a remunerated job is the only way for most women of "buying themselves out" of an unhappy marriage (Goldscheider \& Waite 1991). 


\section{Data and method}

We use the national Spanish Socio-Demographic Survey (SDS) of 1991, which is representative of all Spanish provinces. The sample was drawn from the 1991 census respondents and administrated to some 150.000 people aged 10 years and above. It is a retrospective biographic survey, with union, birth, migration, labor market participation and educational and training histories. As far as this paper is concerned, the survey presents two major problems. First, all events recorded are dated annually (or yearly). Second, union histories ask for the year of union but do not record the year of marriage formation. Nevertheless, it is possible to identify marriages, but we cannot know whether a particular marriage was preceded or not by a cohabitation. On the other hand, cohabitation unions are recorded only if they have not been yet transformed into marriage by the time of the interview.

These two problems have two consequences. First, given that events are dated yearly, it seems more adequate to use a time-discrete methodology (Allison 1987). Second, we will study marriages only. Some may have begun with cohabitation, but unfortunately we have no data on it. With the aim of not adding heterogeneity to our data, first marriages only are included in the analysis.

The discrete-time method for event-history analysis is based on the fact that "the history of an individual or group can always be characterized as a sequence of events" (Allison 1987: 61). We put the original survey data for each respondent into as many lines as the number of years between their $15^{\text {th }}$ birthday and the time of the survey, each line representing one year. For the dependant variable indicating a marital separation, we use the code " 0 " when the individual is at risk (i.e. married) and code "1" in case of marital separation. When an individual is not at risk (i.e. not married or when the case is censored e.g. due to the death of the partner or because he has experienced the event of interest), the value of the variable for this particular year is left blank (missing code). A similar procedure was followed to relate other events (births, for example) and characteristics (age at union formation, employment status) to the dependant variable. Logistic regression is then used for statistical analysis.

Process time $\mathrm{t}$ is the duration of the marital union since its formation. Individuals enter the analysis in 1977, independently of the year of marriage 
formation. Respondents are censored when the spouse dies or they attain their $54^{\text {th }}$ birthday at the survey date (1990). All episodes that took place outside the country and in the cities of Ceuta and Melilla (located in North Africa) are excluded due to data non-availability. Note that by divorce we mean marital dissolution in general, including formal and de facto separation.

Our analysis is restricted to the period after 1976 for two reasons. First, married women under Franco were not always able to freely decide for themselves to engage in work outside the household, i.e. they might have needed the permission of the husband to do so, and divorce was prohibited by law. Second, regular and comparable labor force surveys are available from the third quarter of 1976 onwards only, and 1977 thus represents an appropriate initial year as regards data availability.

In this work, we use a limited but meaningful number of covariates. Most of them are individual level ones, but we also include contextual ones. Apart from the calendar year which can be considered either individual or contextual (depending on the model chosen), our analysis includes three contextual covariates. First, the proportion of non-religious or civil marriages (not celebrated in the church) to the total number of marriages in each of the 50 Spanish provinces. This indicator is fixed for the entire period under analysis and calculated as the average of 1986-1991 period. The proportion of religious marriages is an indicator of traditionalism rather than religiosity. Actual religious participation is low in the country and celebrating a civil marriage indicates a departure from social norms - a sign of modernization in the province. Immediately after the end of the dictatorship in 1975-1976, differentiation in the place of marriage celebration was not high because of strong inertia (during the Franco era, civil marriage was not allowed). For this reason, it is preferable to take this indicator at a later point in time if we want to capture in a meaningful manner the cultural variations in the country ${ }^{4}$.

The two other contextual covariates capture economic opportunities for both men and women, respectively. The discussion on their relation with divorce risks follows the same arguments as for the effect of labor force participation at the individual level (Ruggles 1997, South 1985). However, aggregate data show the effect 
of macroeconomic labor market conditions (independently of current individual situation) on divorce risks. These conditions may capture an anticipatory effect. For example, women with good working opportunities may be more willing to end their marriage even though they are not currently participating in the labor market because the conditions to achieve financial independence are positive (South 1985: 33-34). They may also better reveal the general economic dynamics of the local labor market than individual participation does. The reason behind using two separate indicators is that having a covariate representing the economic opportunities each of the two sexes is facing can serve as a proxy for the economic situation of the other sex. The rationale is, naturally, that the decision to divorce does not depend on one spouse alone, but on both partners.

The choice of these two contextual economic indicators is delicate. Endogeneity must be avoided as much as this is possible. For men, we took the proportion of total unemployed men (total male unemployment rate) as provided by regular labor force surveys $\left(\mathrm{EPA}^{5}\right)$. The indicator is updated annually and taken at the fourth trimester of the preceding year. This means that the indicator for the year 1980 represents the value for October-December of the year 1979. Total male instead of married men unemployment was chosen to avoid, as stressed by Oppenheimer (1997b), possible endogeneity problems. She argued, first, that "men in a more favorable economic position are selected into marriage in the first place" and, second, that "if the marriages of men in poor labor-market positions are more likely to be unstable, then this tends to reduce the number of married men who are unemployed". The consequence of this is that the results would be biased, increasing the expected negative effect of the covariate.

For women, we chose (also from regular labor force surveys) their proportion in the service sector labor force to represent their economic opportunities. As pointed out by Davis (1984) and others, the service sector has driven wives into the labor market. The contextual covariate is computed for the entire employed population, and not only for women. If we used the female population only, our indicator would be

\footnotetext{
${ }^{4}$ We are grateful to Rocío Treviño of the Center for Demographic Studies in Barcelona for the data and the insights of their interpretation.

${ }^{5}$ EPA stands for Encuesta de Población Activa. EPA data are of good quality and fieldwork logistic and survey content follow international practices (Blanes et al, 1996: 115).
} 
biased upwards as the size of the female labor force in services would be greater in those provinces in which divorce rates are higher. The indicator is also updated annually and taken in the fourth trimester of the preceding year.

Coming to the survey's definition of employment, the SDS asked for up to four employment spells; spell being defined as a period of employment in any regime (full-time or part-time, seasonally or not, stable or unstable). According to this definition, unemployment puts an end to an employment spell only if it lasts more than one year. This means that an employment spell can include unemployment spells of less than one year.

The characteristics of employment (e.g. profession, sector of activity) were recorded at the beginning and end of the employment spell. In order not to loose this information, all spells were divided into two sub-spells of the same length, and we attributed the employment characteristics at the beginning of the spell to the first subspell, and the employment characteristic at the end of the spell to the second sub-spell. This is a rough approximation, because we do not know when the change took place, and because there may have been more than one change during an employment spell. Fortunately, most recorded employment spells do not register any change between the first and last job.

We also defined employment differently for men and women. The difference is not striking and it is based on our hypothesis on their effects on divorce risk. For women, the most important feature is the dichotomy between being in employment and not being in employment. For married women, labor force participation clearly represents a new feature of their participation in society in general, and contrasts radically with their situation just a few years before. For men, the male breadwinner system is still in place after the upturn in Spanish politics, and in spite of a growing contribution of women to the labor market, the situation for men has changed little: they still are the main income providers in the household. The dichotomy between employment and unemployment is not sufficient to capture to satisfaction the effect of their labor force participation on divorce risk, given the expectations put on married men. Following Oppenheimer (1994), we use our own measure of unstable labor 
market position defined as being not in employment or having an unstable job (i.e. not having a permanent employment position or contract).

Table 1 displays the list of covariates used in the analysis. Notice that calendar time appears at both the individual and contextual levels. In our view, time may be considered an individual characteristic if we suppose that it constitutes only another form of time dependency, such as age or any kind of duration. However, it is probably much more exact to consider it as a contextual factor as it affects the life of many people that are living in the same household. Time is obviously the necessary complement of space. 
Table 1. List of covariates used in the analysis

\begin{tabular}{|c|c|c|}
\hline Variables & Women & Men \\
\hline \multicolumn{3}{|l|}{ Individual level - fixed } \\
\hline Age difference between spouses & $\mathrm{X}$ & $\mathrm{X}$ \\
\hline Educational attainment $^{6}$ & $\mathrm{X}$ & $\mathrm{X}$ \\
\hline \multicolumn{3}{|c|}{ Individual level - time-dependant/varying } \\
\hline Union duration & $\mathrm{X}$ & $\mathrm{X}$ \\
\hline Current age & $\mathrm{X}$ & $\mathrm{X}$ \\
\hline Calendar time & $\mathrm{X}$ & $\mathrm{X}$ \\
\hline Size of place of residence & $\mathrm{X}$ & $\mathrm{X}$ \\
\hline Number and age of children & $\mathrm{X}$ & $\mathrm{X}$ \\
\hline Employment status & $\mathrm{X}$ & \\
\hline Job stability status & & $\mathrm{X}$ \\
\hline Occupation & $\mathrm{X}$ & $\mathrm{X}$ \\
\hline Professional status & $\mathrm{X}$ & $\mathrm{X}$ \\
\hline Sector of activity & $\mathrm{X}$ & $\mathrm{X}$ \\
\hline \multicolumn{3}{|l|}{ Contextual level - fixed } \\
\hline Proportion of civil marriages & $\mathrm{X}$ & $\mathrm{X}$ \\
\hline \multicolumn{3}{|c|}{ Contextual level- time-dependant/varying } \\
\hline Calendar time & $\mathrm{X}$ & $\mathrm{X}$ \\
\hline $\begin{array}{l}\text { Proportion of the labor force in the } \\
\text { service sector }\end{array}$ & $\mathrm{X}$ & $\mathrm{X}$ \\
\hline $\begin{array}{l}\text { Proportion of male labor force } \\
\text { unemployed }\end{array}$ & $\mathrm{X}$ & $\mathrm{X}$ \\
\hline
\end{tabular}

For the purpose of our analysis, we define our contextual units as a combination of province and year: they are thus time-space contexts. By doing this, we get 700 (50 provinces*14 years) units. This permits us to define contextual covariates as time-dependant and time-varying taking a multi-level approach (our data set includes residential histories, allowing for annual follow-up of people moving across provinces). Given the rapid changes that took place during the Spain in transition and the large heterogeneity of regional social and economic structures, it seems to make sense to have our contextual units defined as time-space units, as this captures both axes of possible contextual determinants on divorce risks.

The intensity logistic (or logit) function takes the following general form:

\footnotetext{
${ }^{6}$ In Spain, especially during the period considered, education for both men and women is completed at marriage.
} 
Logit $p_{i j}(t)=y(t)+\sum_{l} \alpha_{l} x_{i j l}+\sum_{m} \beta_{m} w_{i j m}(t)+\sum_{n} \chi_{n} \gamma_{j n}+\sum_{s} \delta_{s} \varsigma_{j s}(t)+U_{j}$

The intensity of divorce depends on:

- A baseline $y(t)$, which is piecewise constant, where $t$ is duration of marriage.

- Some second or lowest level fixed covariates $\sum_{l} \alpha_{l} x_{i j l}$, including a constant term.

- Some second or lowest level time-dependant and time-varying covariates $\sum_{m} \beta_{m} w_{i j m}(t)$

- Some first or highest level fixed covariates $\sum_{n} \chi_{n} \gamma_{j n}$.

- Some first or highest level time-dependant and time-varying covariates $\sum_{s} \delta_{s} \varsigma_{j s}(t)$.

- And random residuals that capture unobserved heterogeneity of first-level units $j$ $U_{j}$. The $\left\{U_{j}\right\}$ are assumed to be independent of each other.

The logit function, estimated with the software aML (Lillard and Panis 2003), takes two specifications according to how first $(i)$ and second $(j)$ levels are defined. In the first specification, the individual-specification, $i$ stands for calendar year and $j$ for individuals. Here, we suppose that the different "observations" for the same individual (across calendar years) are not independent. In this way we control for unobserved individual variation in the divorce risks (Allison 1987: 82). Variations across provinces are not taken into account.

In the second specification, the contextual-specification, $i$ stands for individuals and $j$ for the combination of province and calendar year. This is similar to the classical multi-level approach. The aim is to control for unobserved province-year variation in the divorce risks ${ }^{7}$. As Courgeau (2002: 108-109) writes, "the outcome for an individual in a particular region often depends on the outcome for other individuals

\footnotetext{
${ }^{7}$ Another possible specification is to let $\mathrm{j}$ be province and $\mathrm{i}$ be individual and calendar year, or even to have a three-level specification (province, individuals and years). Unfortunately, due to too many outcomes per observations, aML is not able to handle both specifications even in the running version "hugeaml" that allocates more memory to scratch arrays. The following error message is returned: "the
} 
living in that region. Ignoring such within-region dependencies generally results in estimated variances of contextual effects that are biased downward".

\section{Results}

Our results are presented in three steps. First, we introduce basic individual and contextual results as obtained from modeling with the two specifications. Second, we examine in more detail the effects of the characteristics of employment on divorce risks; third, we verify interactions between educational and employment characteristics at the individual level. All results are given by sex separately.

Tables $2 \mathrm{a}$ and $\mathrm{b}$ present the results for individual and contextual covariates. There are 8 models. The first four, M01 to M04, do not include any kind of multilevel specification. They were built step-wise, first excluding all socio-cultural and economic covariates (i.e. educational attainment, employment status and the three contextual covariates) and then including them progressively. Results for the full model with individual multi-level are given in model M15. Models M26 to M28 introduce space-time multi-level specifications. M26 is the full model whereas M27 and M28 are variations of this model (explained below). We are not commenting in detail on the results of the demographic, residential and family variables. Let us just say that they support general trends observed in other settings. For example, the effect of being young, living in cities or having had a child before marriage significantly increases the probability of marital dissolution. The effects of education and employment on marital stability are also well known in Spain from other research (Treviño et al 2000, Simó and Solsona 2002). When compared to other industrialized countries, the most striking results are the strong and positive effect of education and the strong but differential effect for men and women of employment on divorce. Individuals with at least a secondary diploma have an odd to separate that is twice higher than that of less educated people. The difference for men is a little more pronounced. Regarding employment, the effect is strong as well, but has an impact that is different for men: Not being in employment or having an unstable job increases their marital dissolution risk by more than two $^{8}$. For women, the opposite applies:

maximum dimension of scratch arrays is exceeded". For more details, see http://www.applied$\mathrm{ml} . \mathrm{com} / \mathrm{support/faq.html \# memory.}$

${ }^{8}$ For convenience, we use risk as synonym for odd and relative risk as synonym for odds-ratio. 
being in employment multiplies their probability of divorce by 2.5. An explanation behind this relation could nevertheless stem from the same logic as for men: The presence of the male breadwinner (and wife housemaker) model of marriage. This issue is addressed in more detail below.

Table 2 also presents results for the three contextual covariates. They are proportional and continuous. The proportion of civil marriage is considered a proxy for non-traditionalism in the province, whereas the proportion of the labor force in the service sector and the total male unemployment rate represent two approximate measures for female and male economic opportunity in local labor markets, respectively. The three covariates display the expected sign in the five models where they are included. Characteristic of models M26, M27 and M28 is that a space-time multi-level model is specified. In M26, the three contextual covariates are entered with all individual covariates. In M27, the individual employment covariate is removed from the model to see the effect on the corresponding contextual employment covariate In M28, we have done the opposite by re-introducing the individual employment covariate and removing the corresponding contextual employment covariate. The aim of running M27 and M28 is to test for a possible association between individual and contextual labor market effects.

One can see that the male unemployment rate does not have a statistically significant effect on divorce risk, although the effect is a positive (it has the "right" sign) and an important one (odds-ratio of around 1.5 per women and 2 for men). Maybe unemployment, given its high level in the country, is not a good "indicator of personality traits that could be associated with incompetence in both the employment and marital spheres"(Bracher et al. 1993: 420). People may be aware of the existence of labor market deficiencies and only a long spell in unemployment or an unstable employment position, captured by an individual covariate, may increase divorce risks for men. Given the small number of these person-years (see the table-annex at the end), these situations are probably related more to men's extreme personal characteristics such as alcohol or violence abuses than to labor market integration per se. 
The effect of non-traditionalism or having many civil marriages is very important and significant for men, but much less so for women and non-significant within a contextual multi-level setting. When deciding to divorce, are men more "sensitive" than women are to socio-cultural conditions? Given that for men, the labor market context (male provincial unemployment rate) has a neutral effect on divorce, the socio-cultural setting may easily capture regional variations of the phenomenon. This point is discussed further in the last part. As to the women's economic opportunity contextual covariate, we find that the proportion of the labor force in the service sector is highly positively related to marital separation rates for both women and men. The effect is clearly stronger for females and overshadows the impact of contextual socio-cultural factors. Even when removing the individual employment covariate for women, the effect remains high and significant. The service sector contextual covariate has thus a strong positive effect on divorce risks, which is quite independent of women's employment status.

For men the effect of socio-cultural context is stronger than the two economic contextual covariates. In fact, when we look carefully at individual covariates, we notice a similar differentiation for educational and employment status: the effect of employment is stronger for wives than for husbands, but the effect of education is slightly stronger for the former. Are women driven by economic considerations to a greater extent than men are when they opt for divorce? To address this question, we need to turn to an in-depth examination of men's and women's work characteristics and their effects on divorce.

In Figure 4, relative divorce risks are calculated for persons in employment only (employed women and men in stable employment as previously defined) for three work characteristics: group of occupation, professional category (or socioprofessional position) and activity sector of the firm. We estimated the full model M15 three times (including one of these characteristics at a time), separately for each sex. Only results for our covariates of interest are presented here. For women (Figure 4a), all coefficients are statistically significant at least at 0,10; for men (Figure 4b), bars representing significant coefficients are colored in dark blue. 
Table 2a. Odds-ratios and heterogeneity component. Results of logistic regression on divorce risks in Spain, 1977-1990.

\section{Women}

M01 to M04: without multi-level specification

M15: with individual multi-level specification (see text)

M26 to M28: with contextual multi level specification (see text)

\begin{tabular}{|c|c|c|c|c|c|c|c|c|c|}
\hline Covariate & Value & M01 & M02 & M03 & M04 & M15 & M26 & M27 & M28 \\
\hline Marriage & 0 & 1 & 1 & 1 & 1 & 1 & 1 & 1 & 1 \\
\hline Duration & $1-3$ & 3.56 *** & $3.64^{* * *}$ & $3.94^{* \star *}$ & $3.92^{* * *}$ & $4.05^{* * *}$ & 3.92 *** & 3.60 *** & $3.92 * * *$ \\
\hline \multirow[t]{3}{*}{ in years } & $4-9$ & $9.71 * * *$ & $10.36^{* * *}$ & $10.89 * * *$ & $10.81^{* * *}$ & $11.43^{* * *}$ & $10.81^{* * *}$ & $10.12^{* * *}$ & $10.80 * * *$ \\
\hline & $10-21$ & $9.51^{* * *}$ & $10.95^{* * *}$ & $11.73^{* * *}$ & $11.70^{* * *}$ & $12.69 * * *$ & $11.57^{* * *}$ & $10.57^{* * *}$ & $11.55 * \star *$ \\
\hline & $22-41$ & $4.85^{* * *}$ & $6.01^{* * *}$ & $6.67^{* \star *}$ & $6.72^{* * *}$ & $7.12^{* * *}$ & $6.68^{* * *}$ & $5.90 * * *$ & $6.61 * * *$ \\
\hline \multirow[t]{3}{*}{ Current age } & 24 and less & 1 & 1 & 1 & 1 & 1 & 1 & 1 & 1 \\
\hline & $25-34$ & $0.41^{* * *}$ & $0.38^{* * *}$ & $0.37^{* \star *}$ & $0.37^{* * *}$ & $0.39^{* * *}$ & $0.36 * * *$ & $0.38^{* * *}$ & $0.36 * \star \star$ \\
\hline & $35-54$ & $0.24 * * *$ & $0.24^{* * *}$ & $0.24^{* * *}$ & $0.23^{* * *}$ & $0.24^{* * *}$ & $0.23^{* * *}$ & $0.24^{* * *}$ & $0.23 * * *$ \\
\hline Calendar & $77-81$ & 1 & 1 & 1 & 1 & 1 & 1 & 1 & 1 \\
\hline Year & $82-90$ & $1.99 * * *$ & $1.83^{* * *}$ & $1.75^{* * *}$ & $1.57^{* * *}$ & $1.67^{* * *}$ & $1.54 * * *$ & $1.64^{* * *}$ & $1.62 * \star *$ \\
\hline \multirow[t]{2}{*}{ Out-of-wedlock birth } & No & 1 & 1 & 1 & 1 & 1 & 1 & 1 & 1 \\
\hline & Yes & $1.48^{* * *}$ & $1.56^{* \star \star}$ & $1.55^{* * *}$ & $1.58^{* \star *}$ & $1.62^{* \star *}$ & $1.57^{* \star *}$ & $1.58^{* * *}$ & $1.55 * * *$ \\
\hline Age difference between & Normal (-3 to 15$)$ & 1 & 1 & 1 & 1 & 1 & 1 & 1 & 1 \\
\hline husband and wife & Other & $1.78^{* * *}$ & $1.81^{* \star *}$ & $1.75^{* * *}$ & $1.75^{* * *}$ & $1.80^{* * *}$ & $1.74 * * *$ & $1.80^{* * *}$ & $1.74 * * *$ \\
\hline Size of place of & $5000-$ & 1 & 1 & 1 & 1 & 1 & 1 & 1 & 1 \\
\hline \multirow[t]{3}{*}{ residence } & $5001-20000$ & $2.35^{* \star *}$ & $2.34^{\star \star *}$ & $2.36^{* \star *}$ & $2.28^{* \star *}$ & $2.34^{\star \star *}$ & $2.26^{\star \star \star}$ & $2.25^{\star * *}$ & $2.32 * * *$ \\
\hline & $20001-100000$ & $2.58^{* * *}$ & $2.49^{* \star *}$ & $2.54^{* \star *}$ & $2.34^{* * *}$ & $2.42^{* \star *}$ & $2.32^{* * *}$ & $2.28^{* * *}$ & $2.45 * * *$ \\
\hline & $100001+$ & $4.33^{* * *}$ & $3.92 * * *$ & $3.96 * * *$ & $3.47^{* * *}$ & $3.65^{* * *}$ & $3.44 * * *$ & $3.41^{* * *}$ & $3.80 * \star \star$ \\
\hline Family structure & No children (40 -) & 1 & 1 & 1 & 1 & 1 & 1 & 1 & 1 \\
\hline \multirow[t]{3}{*}{ (age of wife) } & 1 minor child & 0.88 & 0.93 & 1.06 & 1.07 & 1.09 & 1.07 & 0.93 & 1.06 \\
\hline & $2+$ minor children & $0.51^{* * *}$ & $0.55^{* * *}$ & $0.69 * * *$ & $0.69^{* * *}$ & $0.69^{* * *}$ & $0.69 * * *$ & $0.56 * * *$ & $0.69 * \star \star$ \\
\hline & Other situations & $0.46^{* * *}$ & $0.51^{* * *}$ & $0.61 * *$ & $0.62 * *$ & $0.62 * *$ & $0.62 * *$ & $0.51 * * *$ & $0.62 * *$ \\
\hline
\end{tabular}

Continuation on next page.... 
Table 2a - Women (continuation)

\begin{tabular}{|c|c|c|c|c|c|c|c|c|c|}
\hline Covariate & Value & M01 & M02 & M03 & M04 & M15 & M26 & M27 & M28 \\
\hline \multirow[t]{3}{*}{ Education attainment } & No education & & 1 & 1 & 1 & 1 & 1 & 1 & 1 \\
\hline & Primary completed & & 1.13 & 1.13 & 1.14 & 1.17 & 1.13 & 1.14 & 1.13 \\
\hline & Secondary compl. & & $2.06^{* * *}$ & $1.61^{* * *}$ & 1.62 *** & $1.70^{* * *}$ & $1.60 * * *$ & $2.02 * * *$ & $1.60 * * *$ \\
\hline \multirow[t]{2}{*}{ Employed } & No & & & 1 & 1 & 1 & 1 & & 1 \\
\hline & Yes & & & $2.60^{* * *}$ & $2.61^{* \star *}$ & $2.75^{\star \star *}$ & $2.56^{* \star *}$ & & $2.57 * * *$ \\
\hline Prop. civil marriages & Continuous & & & & 2.06 * & $2.33^{*}$ & 1.75 & 1.83 & 1.28 \\
\hline Prop. act. pop. in services & Continuous & & & & $6.56^{* \star *}$ & $7.54 * * *$ & $7.16^{* * *}$ & $8.18^{* * *}$ & \\
\hline Male unemployment rate & Continuous & & & & 1.56 & 1.57 & 1.44 & 1.03 & 1.80 \\
\hline \multicolumn{6}{|c|}{ Standard deviation of the heterogeneity component } & $1.23 * * *$ & $0.23^{* * *}$ & $0.28^{* * *}$ & $0.26 * * *$ \\
\hline
\end{tabular}

Significance: $*=10 \% ; * *=5 \%$; $* * *=1 \%$.

Source: Own calculations from INE, Sociodemographic Survey, 1991 
Table 2b. Odds-ratios and heterogeneity component. Results of logistic regression on divorce risks in Spain, 1977-1990.

Men

M01 to M04: without multi-level specification

M15: with individual multi-level specification (see text)

M26 to M28: with contextual multi level specification (see text)

\begin{tabular}{|c|c|c|c|c|c|c|c|c|c|}
\hline Covariate & Value & M01 & M02 & M03 & M04 & M15 & M26 & M27 & M28 \\
\hline Marriage & 0 & 1 & 1 & 1 & 1 & 1 & 1 & 1 & 1 \\
\hline duration & $1-3$ & $4.10^{* * *}$ & $4.12^{* * *}$ & $4.42^{* \star *}$ & $4.36^{* \star *}$ & $4.39^{* * *}$ & $4.39^{\star \star \star}$ & $4.08^{* * *}$ & $4.38^{* * *}$ \\
\hline \multirow[t]{3}{*}{ in years } & $4-9$ & $8.49^{* * *}$ & $8.62^{* * *}$ & $9.35^{* * *}$ & $9.10^{* * *}$ & $9.28^{* * *}$ & $9.07^{* * *}$ & $8.37^{* * *}$ & $9.04^{* * *}$ \\
\hline & $10-21$ & $8.13^{* * *}$ & $8.64^{* * *}$ & $9.39^{* * *}$ & $9.07^{* * *}$ & $9.33^{* * *}$ & $8.91^{* * *}$ & $8.22 * * *$ & $8.86^{* * *}$ \\
\hline & $22-41$ & $4.65^{* * *}$ & $5.35^{* * *}$ & $5.62 * * *$ & $5.49 * * *$ & $5.58^{* * *}$ & $5.37^{* \star *}$ & $5.15^{* * *}$ & 5.34 *** \\
\hline \multirow[t]{3}{*}{ Current age } & 24 and less & 1 & 1 & 1 & 1 & 1 & 1 & 1 & 1 \\
\hline & $25-34$ & $0.44^{* * *}$ & $0.41^{* * *}$ & $0.43^{* * *}$ & $0.44^{* * *}$ & $0.44^{* * *}$ & $0.43^{* * *}$ & $0.41^{* * *}$ & $0.43^{* * *}$ \\
\hline & $35-54$ & $0.21^{* * *}$ & $0.21^{* * *}$ & $0.22^{* * *}$ & $0.22^{* * *}$ & $0.22^{* * *}$ & $0.22^{* * *}$ & $0.21^{* * *}$ & $0.22^{* * *}$ \\
\hline Calendar & $77-81$ & 1 & 1 & 1 & 1 & 1 & 1 & 1 & 1 \\
\hline year & $82-90$ & $1.83^{* * *}$ & $1.74^{* * *}$ & $1.73^{* * *}$ & $1.57^{* \star *}$ & $1.60^{* * *}$ & $1.56^{* * *}$ & $1.56^{* * *}$ & $1.64^{* * *}$ \\
\hline \multirow[t]{2}{*}{ Out-of-wedlock birth } & No & 1 & 1 & 1 & 1 & 1 & 1 & 1 & 1 \\
\hline & Yes & $1.76^{* \star *}$ & $1.83^{* * *}$ & $1.80^{* * *}$ & $1.81^{* * *}$ & $1.84^{* * *}$ & $1.80^{* * *}$ & $1.84^{* * *}$ & $1.80^{* * *}$ \\
\hline Age difference between & Normal (-3 to 15$)$ & 1 & 1 & 1 & 1 & 1 & 1 & 1 & 1 \\
\hline husband and wife & Other & 1.32 * & $1.32 *$ & $1.33^{*}$ & $1.33^{*}$ & 1.34 * & 1.31 & 1.31 & 1.31 \\
\hline Size of place of & $5000-$ & 1 & 1 & 1 & 1 & 1 & 1 & 1 & 1 \\
\hline \multirow[t]{3}{*}{ residence } & $5001-20000$ & 1.01 & 0.99 & 0.98 & 0.94 & 0.94 & 0.93 & 0.94 & 0.94 \\
\hline & $20001-100000$ & $1.56^{* * *}$ & $1.49^{* * *}$ & $1.48^{* * *}$ & 1.33 * & 1.34 * & $1.32 *$ & $1.33 *$ & 1.34 * \\
\hline & $100001+$ & $2.36^{* \star *}$ & $2.12^{* * *}$ & $2.11^{* * *}$ & $1.86^{* * *}$ & $1.87^{* * *}$ & $1.84^{* * *}$ & $1.85^{* * *}$ & $1.86^{* * *}$ \\
\hline Family structure & No children (40 -) & 1 & 1 & 1 & 1 & 1 & 1 & 1 & 1 \\
\hline \multirow[t]{3}{*}{ (age of wife) } & 1 minor child & $0.74^{* * *}$ & $0.77^{* *}$ & $0.77^{* *}$ & $0.78 * *$ & $0.78^{* *}$ & $0.78 *$ & $0.78^{* *}$ & $0.78 *$ \\
\hline & $2+$ minor children & $0.53^{* * *}$ & $0.56^{* * *}$ & $0.56^{* * *}$ & $0.57 * * *$ & $0.57^{* \star *}$ & $0.58^{* * *}$ & $0.57^{* * *}$ & $0.58^{* * *}$ \\
\hline & Other situations & $0.63^{* *}$ & $0.68 *$ & $0.67^{*}$ & 0.68 * & 0.68 * & 0.69 & 0.69 & 0.69 \\
\hline
\end{tabular}


Continuation on next page...

Table $2 \mathrm{~b}$ - Men (continuation)

\begin{tabular}{|c|c|c|c|c|c|c|c|c|c|}
\hline Covariate & Value & M01 & M02 & M03 & M04 & M15 & M26 & M27 & M28 \\
\hline \multirow[t]{3}{*}{ Education attainment } & No education & & 1 & 1 & 1 & 1 & 1 & 1 & 1 \\
\hline & Primary completed & & 1.20 & 1.25 * & $1.28^{* *}$ & $1.28^{* *}$ & 1.26 * & 1.21 & 1.25 * \\
\hline & Secondary compl. & & $1.82^{* * *}$ & $1.91^{* * *}$ & $1.97^{* * *}$ & $1.98^{* * *}$ & $1.92^{* * *}$ & $1.84^{* * *}$ & $1.91^{\star \star \star *}$ \\
\hline \multirow[t]{2}{*}{ Employment } & Absence or unstable & & & $2.12^{* \star *}$ & $2.12^{* * *}$ & $2.14^{* \star *}$ & $2.11^{* * *}$ & & $2.11^{\star \star \star}$ \\
\hline & Stable & & & & 1 & 1 & 1 & & 1 \\
\hline Prop. civil marriages & Continuous & & & & $10.98^{* * *}$ & $11.39^{* \star *}$ & $7.87^{* * *}$ & $7.80^{* * *}$ & $8.26^{\star \star \star}$ \\
\hline Prop. act. pop. in services & Continuous & & & & $3.10^{* *}$ & 3.20 ** & 3.70 ** & 3.54 ** & 3.89 ** \\
\hline Male unemployment rate & Continuous & & & & 1.97 & 1.97 & 1.81 & 2.07 & \\
\hline \multicolumn{6}{|c|}{ Standard deviation of the heterogeneity component } & $0.92 * *$ & $0.31^{* * *}$ & $0.31^{* * *}$ & $0.31^{* * *}$ \\
\hline
\end{tabular}

Significance: $*=10 \% ; * *=5 \% ; * * *=1 \%$.

Source: Own calculations from INE, Sociodemographic Survey, 1991 
Figure 4a. Odd-ratios of divorce by work characteristics, 1977-1990. Employed Women.
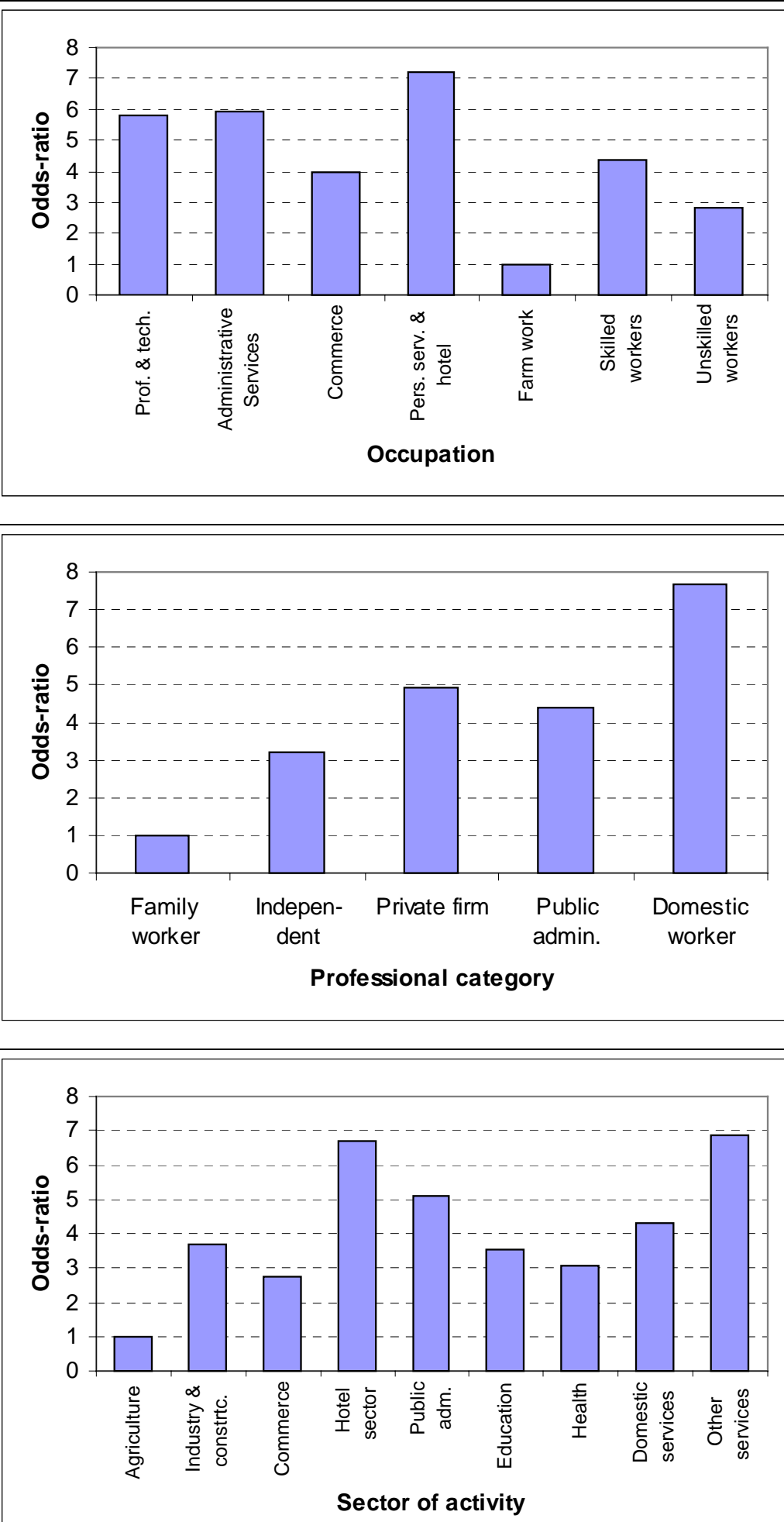

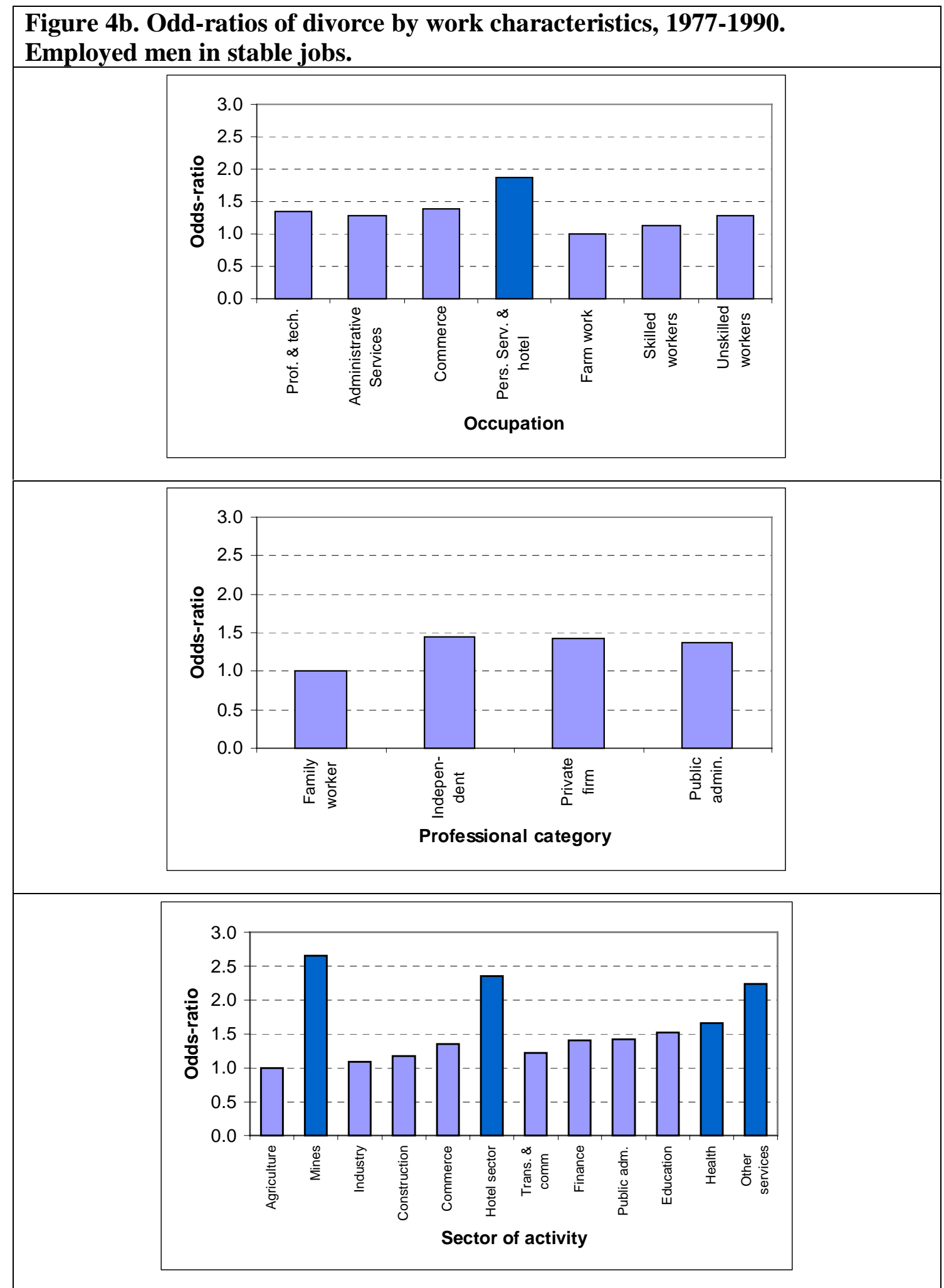

Source: Own calculations from INE, Sociodemographic Survey, 1991

Note: For women, all coefficients are significant at 0.1 level. For men, significant coefficients are colored in dark blue. 
Results from Figure 4, coupled with those from Table 3, suggest the existence of some kind of non-linear relationship between socio-economic characteristics and divorce. People situated at the two extremes of the social dichotomy have the highest divorce risks (above the average). On one side of the dichotomy, there are workers with labor market positions that are generally held to be relatively unrewarding when compared to other employment positions: in the hotel and catering sector, in mining, domestic work and other services - mostly personal services. In Spain, the hotel and catering industry is strongly associated with the tourist sector, which is characterized by low salaries and seasonal work. Domestic employment (caring for children and old people etc.) and personal services are probably not as seasonal, but salaries are also very low. These types of work are easily accessible and see relatively high rates of work force turnover. The mining sector is witnessing a crisis in many regions in Spain, such as in Asturias, and this surely contributes to the destabilization of marriage of the Austurian population. On the other extreme of the dichotomy, higher educated people (with at least a secondary school diploma) equally show divorce risks above that of other groups. As mentioned before, this fact is well documented. Paradoxically, higher education and enjoying a financially and / or otherwise very rewarding good position in the labor market does not seem to affect divorce the same way.

In view of this result, we can assert that Becker's independence hypothesis does not apply to the context of this study. The types of jobs associated with higher work stability and income, such as being a professional or a technician, working in public administration or an employee in the finance sector, do not translate into higher divorce risks for wives, and are not associated to marital stability for husbands either. In fact, the opposite applies in both cases. Female workers in the hotel and catering sector, in domestic jobs and personal (other) services, i.e. with positions that are either very unstable or seasonal and not well paid, have the highest propensity to divorce. A comparable conclusion holds for men. Those in the hotel/catering sector, mining and personal services face higher divorce risks. Neverthless, lowest risks are not observed in the most stable jobs, as in the public sector or in professional and technical employment. 
In Figure 5, relative divorce risks, estimated from the full model M15, are graphed to highlight the interaction between employment status and detailed educational level (5 categories instead of 3 ). As to the employed, we make a distinction between "high divorce" and "low divorce" jobs. We have just seen that some types of jobs are more associated with divorce than others. High divorce jobs are those that have at least one the following characteristics:

\begin{tabular}{ll}
\hline For women & For men \\
\hline Occupation: & Occupation: \\
Personal services, hotel and catering & Personal services, hotel and catering \\
\hline Professional category: & - \\
Domestic worker & \\
\hline Sector of activity: & Sector of activity: \\
Hotel and catering sector & Mines \\
Other services & Hotel and catering sector \\
& Other services \\
\hline
\end{tabular}

The reminder is low divorce jobs.

We distinguish a "U" shape curve in the graph for the employed in high divorce jobs for men and above all for women. The "U" shape attests to the existence of two high-divorce groups in the population. As far as women are concerned, these are workers in high divorce jobs with no education who exhibit a very high divorce probability compared to the female population, and then by the reminder of women in the labor market with some completed formal education. In contrast, women who are not employed and those who work as family workers and in the agricultural sector (see Figure 4a) show the lowest propensity of marital disruption. Men show less disparity between the employment groups. Higher divorce probabilities are found among the (long-term) unemployed or those with an unstable job (the reference category in Graph 5) and those with university education working in high divorce jobs. However, both groups represent very few person-years. The difference in divorce risks between low and high divorce jobs is not higher than for women (the difference of scale between men and women must not mislead us), and there is only a slight positive interaction effect between having no education and having a high 
divorce job. In relation to divorce, men are more differentiated in terms of educational attainment than are women, even though the difference is not large.

\section{Figure 5. Odd-ratios of divorce by employment type and educational attainment, 1977-1990. Women and Men}

Women (ref: blank circle)

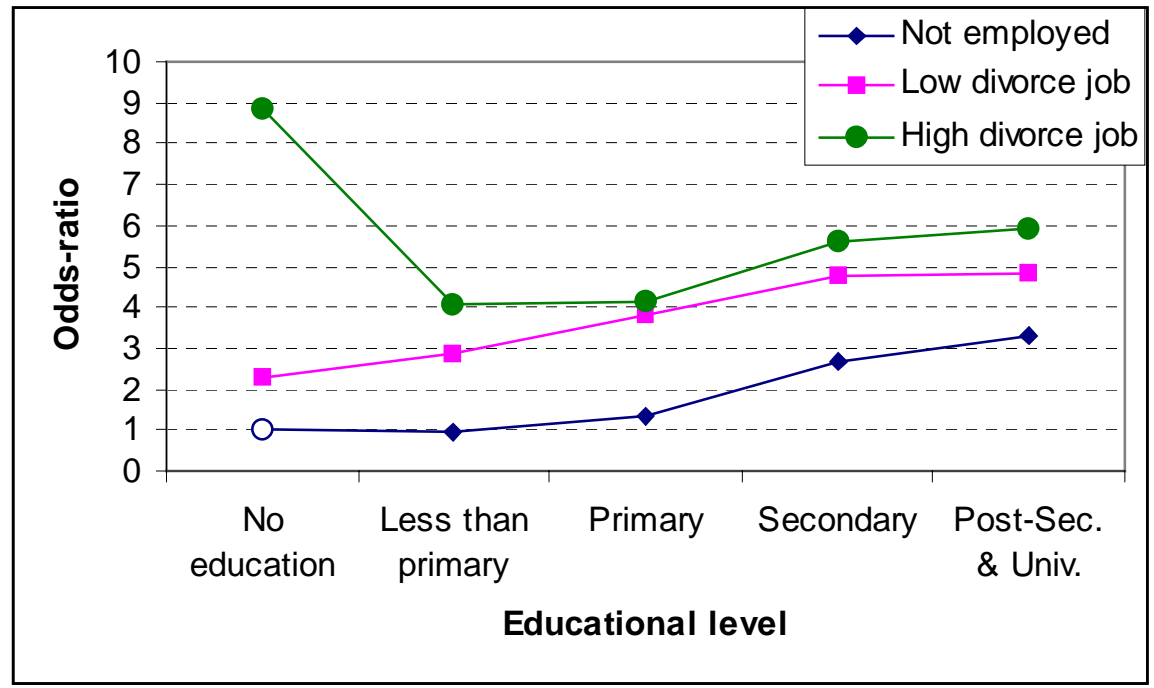

Men (ref: not employed or with unstable job=1)

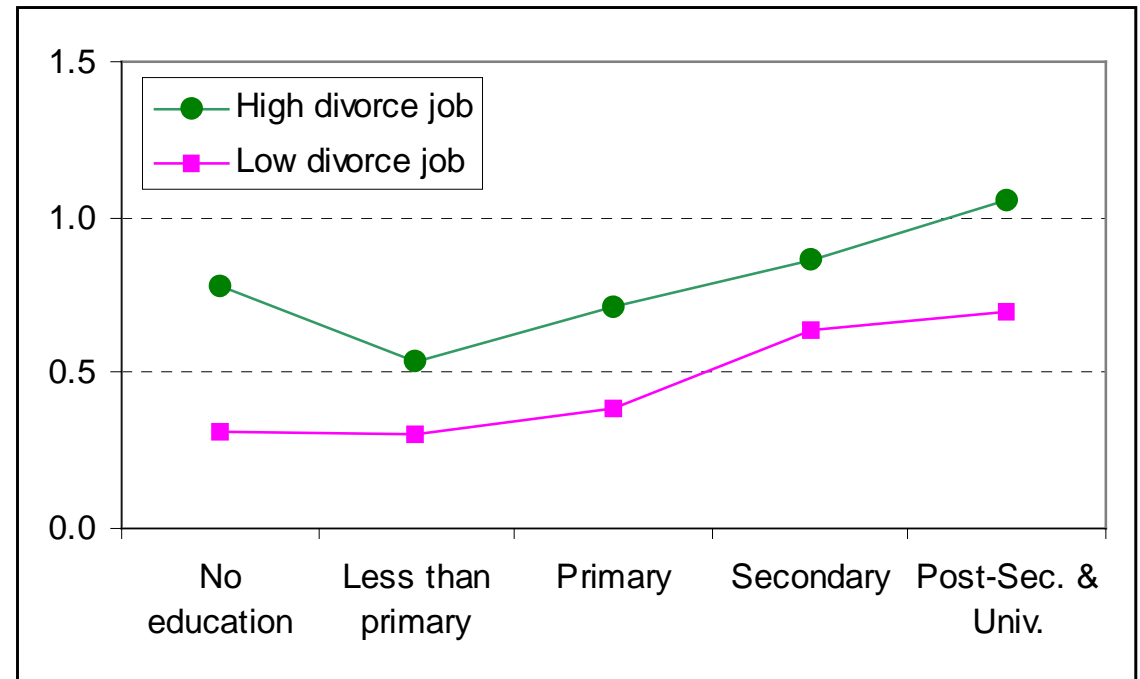

Source: Own calculations from INE, Sociodemographic Survey, 1991 


\section{Discussion}

Two main results emerge from our work. The first one deals with the differential effect by sex of contextual covariates on divorce risks. For women, a strong positive association between proportion of the labor force in the service sector in provinces and marital disruption has been found. This effect is independent of wives' actual participation in the labor market. For men, the socio-cultural context is stronger than the economic opportunity effect. The other important result is the presence of a " $U$ " shape curve linking divorce with socio-economic characteristics. Divorce risks tend to be higher at the opposite ends of the socio-economic structure (measured as the combination of education and labor market integration), a fact that is more pronounced for women than men.

Both results are linked to the particular context of Spanish society in transition. The political transition brought about parallel changes in the economic sphere and the society. Women's position in society and on the labor market changed in a radical way, which means that they could now decide for themselves on important matters in their lives. For some, calling into question their marriage became a valid option - but not viable one if one considers the necessity to have financial resources to sustain a household, often with young children, of their own. State intervention in family affairs was (and still remains) meager, as the state continues to base it's family orientation on the male breadwinner model, leaving little room for the emerging new family forms. This crude reality meant that wives who wanted to end their marriage, or faced a divorce or a separation, had to be able to rely on or provide some source of stable income. It is then not surprise that working wives show divorce risks twice as high as the non-working female population. The fact that the relative size of the service sector is so strongly and positively related to divorce risks proves that work per se is not a cause of divorce, but rather a means to reach or to cope with an anticipated or a new situation.

Men appear to respond to other stimuli. During the period under study, most Spanish husbands participated in the labor market. The question of securing an income in case of marital separation was not high on their list of daily priorities, even 
though unemployment rates were growing rapidly ${ }^{9}$. The reason is that they face the financial consequences of divorce with less acuity, not only because they have easier access to the labor market, but also because they generally do not receive or desire to have custody of the children. The strong and positive effect of a less traditional cultural context expressed in declining acceptance of catholic marriage (proportion of civil marriage to the marriage total) may reflect the changing norms and values in the population during transition. A more liberal (or permissive) view on women's role in society and marital breakdown is part of this value change. It facilitated on both sides of the union the decision to divorce. Moreover, the effect of the service sector is positive and significant also for men, albeit to a lower degree than for women, and having an effect that is independent from the socio-cultural contextual factor ${ }^{10}$. But why is the effect of civil marriage not visible in our analysis on women? We cannot provide a full answer here, and can only put forward one hypothesis: regional variations in divorce are entirely captured by the service sector contextual covariate, and this is due to the important function that financial and economic security takes for women who deciding to separate. It is worth highlighting once again that our results from contextual covariates tend to show that paid employment is not a direct cause of divorce for wives, as hypothesized in the marriage trading model, but rather a prerequisite for and even a consequence of it $^{11}$. They together illustrate how economic and socio-cultural factors contribute to explaining regional variations in divorce rates in a heterogeneous country such as Spain. The effect of men's labor market up and down movements (as seen when looking at unemployment rates) seems to play a marginal role only.

A second set of results concerns the differential character of divorce from the socio-economic individual perspective. Again, men and women exhibit significant differences when the subject is examined more in-depth by educational levels and employment characteristics and then by introducing them in interaction in the modeling. This was done in Graphs 4 and 5. We have been able to show that the

\footnotetext{
${ }^{9}$ Between 1975 and 1990 , the total male unemployment rate grew frorm $4,5 \%$ to $11,9 \%$, with a maximum level of 20\% reached in 1985 (Blanes et al. 1996, table 2.7).

${ }^{10}$ After removing the covariate "prop. civil marriages" from model M26 for men, the value of "prop. act. pop. in services" hardly changes (3.43 against 3.70 in table $2 b$ ).

${ }^{11}$ Some authors in fact argue that women may enter the labor market during marriage in anticipation of their marriage break-up (Becker et al. 1977; Oppenheimer 1997a) or because they face rising divorce probability (Johnson \& Skinner 1986).
} 
decision to divorce greatly varies across socio-professional and educational groups. At first glance, divorce in Spain appears to be most pronounced in those with higher education (with at least a secondary school diploma), in working wives and unemployed men. Except for the latter group, high divorce groups are composed of people situated in the highest strata of society. This evidence seems to support the view that in societies where divorce is not widespread individuals with high financial and intellectual capital are better equipped to cope with the consequences of divorce. This proposition is applicable to the Franco regime, as social norms were very strong and women highly dependent on men. With the transition, however, the divorce situation in Spain began to develop towards an increasingly diversified set of opportunities for both sexes. Family decisions and divorce are also experiencing transition. We have seen in Graph 4 the extent of variations in divorce risks by socioprofessional groups. One of the most striking features is the absence of a very clear pattern, except that highest risks are characteristic of few groups or sectors, mostly the same for women and men. However, there is an interesting paradox in relation to what one might expect in relation to the trend by education - that these groups are situated at the less favorable position on the socio-professional scale. The hotel and catering sector is a good example.

These groups or sectors, with the exception of mining, are easy to enter because there is a relative abundance of employment positions that rarely offer a very stable or fixed work situation, and they are not very well paid. As regards women, they constitute a convenient solution for those who are looking for a first job. High divorce risks in these sectors are also due to an anticipation effect, especially for women in very unstable marriages. To some extent, given that long-term unemployed men also display high risks of divorce, one may wonder whether these reflect basically a mirror effect of the other, or vice versa. The high level of endogamy by socio-economic characteristics of Spanish marriages supports this hypothesis (González 2000). There probably exists a sector in society where divorce is very high due to very unstable labor market positions and the presence of extreme personal behaviors. This sector would consist of both men and women who are not well integrated into the labor market (and probably in the society, too, in general) and with a very low education. 
Our final conclusion is to confirm transition in Spain regarding family behaviors, including divorce. Its causes are similar to what the SDT proposes: the growing labor force participation of women, value change, and institutional adaptations. However, its has been slowed down by the reminiscences of strong social norms inherited from the previous regime and by the present conservative nature of the welfare system based on the breadwinner model of marriage more so than the dual earners families model. This situation provokes distortions in the adaptation of families to their new economic and cultural environment (a consequence being the very low fertility of Spanish couples) and maintains some sort of inequality as to the access of resources when being in unstable marriages, especially for women (and their children). 


\section{References}

Allison, P. 1987. "Discrete-time Methods for the Analysis of Event Histories". Sociological Methodology, 12: 61-98.

Baizán, P., F. Michielin and F. Billari. 2002. "Political Economy and Life Course Patterns: The Heterogeneity of Occupational, Family and Household Trajectories of Young Spaniards.” Demographic Research, 6: 191-240.

Becker, G. S., E. M. Landes and R. T. Michael. 1977. "An Economic Analysis of Marital Instability”. The Journal of Political Economy, 85: 1141-1188.

Blanes, A., F. Gil and J. Pérez. 1996. Població i activitat a Espanya: evolució $i$ perspectives, Barcelona, La Caixa.

Blossfeld, H.-P., A. De Rose, J.M. Hoem, and G. Rohwer. 1995. "Education, Modernization, and the Risk of Marriage Disruption in Sweden, West Germany, and Italy." In: Oppenheim Mason, K. and A.-M. Jensen (Eds.). Gender and Family Change in Developed Societies, pp. 200-222.

Bracher, M., G. Santow, S. P. Morgan and J. Trussell. 1993. "Marriage Dissolution in Australia: Models and Explanations." Population Studies, 47: 403-425.

Cherlin, A. 1992. Marriage, Divorce, Remarriage. Revised and Enlarged Edition. Cambridge, Harvard University Press.

Conseil de l'Europe. 1997. Evolution démographique récente en Europe. Strasbourg, Editions du Conseil de l'Europe.

Courgeau, D. 2002. "New Approaches and Methodological Innovations in the Study of Partnership and Fertility Behaviour." In Macura, M. and G. Beets (Eds). Dynamics of fertilty and partnership in Europe. Insights and lessons from comparative research. Volume I. Geneva, United Nations, pp. 99-114.

Davis, K. 1984. "Wives and Work: The Sex Role Revolution and its Consequences." Population and Development Review, 10: 397-417.

Esping-Andersen, G. 1997. "Welfare States without Work: the Impasse of Labour Shedding and Familialism in Continental European Social Policy". In EspingAndersen, G. (Ed.), Welfare States in Transition. National Adaptations in Global Economies, London, Sage Publications.

Esping-Andersen, G. 1999. Social Foundations of Postindustrial Economies. Oxford, Oxford University Press.

Goldscheider, F. K. and L. J. Waite. 1991. New Families, No Families? Berkely, University of California Press.

González, M. J. 2000. "Partnership Formation in the Context of Women's Growing Educational Attainment." Universitat Autonoma de Barcelona, Centre d'Estudis Demographics. Papers de Demografia no. 180.

González, M. J., T. Jurado and M. Naldini. 1999. "Introduction: Interpreting the Transformation of Gender Inequalities in Southern Europe." In González, M. J., T. Jurado and M. Naldini (Eds.). Gender Inequalities in Southern Europe. Women, Work and Welfare in the 1990s. London, Frank Cass, pp. 4-34. 
Hoem, J. M. 1997. "Educational Gradients in Divorce Risks in Sweden in Recent Decades." Population Studies, 51: 19-27.

Johnson, W. R. and J. Skinner. 1986. "Labor Supply and Marital Separation". The American Economic Review, 76: 455-469.

Lesthaeghe, R. 1983. "A Century of Demographic and Cultural Change in Western Europe: An Exploration of Underlying Dimensions." Population and Development Review, 9: 411-435.

Lillard, L. A. and C. W. A. Panis. 2003. aML Multilevel Multiprocess Statistical Software, Version 2.0. Los Angeles, EconWare.

Liu, G. and A. Vikat. 2004. "Does divorce Risk Depend on Spouses' Relative Income? A Register-Based Study of First Marriages in Sweden in 1981-1998." MPIDE Working Paper, WP 2004-010.

Monnier, A. 1999. “La conjoncture démographique.” Population, 54: 745-774.

Oppenheimer, V. K. 1994. "Women's Rising Employment and the Future of the Family in Industrial Societies." Population and Development Review, 20: 293-342.

Oppenheimer, V. K. 1997a. "Women's Employment and the Gain to Marriage: The Speicialization and Trading Model." Annual Review of Sociology, 23: 431-453.

Oppenheimer, V. K. 1997b. "Comment on The Rise of Divorce and Separation in the United States, 1880-1990.” Demography, 34: 467-472.

Reher, D. 1997. Perspectives on the Family in Spain, Past and Present. Oxford, Clarendon Press.

Ruggles, S. 1997. "The Rise of Divorce and Separation in the United States, 18801990." Demography, 34: 455-466.

Simó, C. and M. Solsona. 2002. "Impoprtancia de la participación laboral como determinante del divorcio en España." Universitat Autonoma de Barcelona, Centre d'Estudis Demographics. Papers de Demografia no. 210.

Solsona, M., R. Houle and C. Simó. 2000. "Separation and divorce in Spain.” In González, M. J., T. Jurado and M. Naldini (Eds). Gender Inequalities in Southern Europe. Women, Work and Welfare in the 1990s. London, Frank Cass, pp.195-222.

South, S. J. 1985. "Economic Conditions and the Divorce Rate: A Time-Series Analysis of the Postwar United States." Journal of Marriage and the Family, 47:3141.

Treviño, R., M. Solsona, C. Simó and R. Houle. 2000. "Los determinantes sociodemográficos y familiares de las rupturas de uniones en España: la nomalización del fenómeno." Boletín de laAsociación de Demografía Histórica, XVIII: 101-135. 
Table annex: Distribution of person-years in marriage and events (marital separations)

\begin{tabular}{|c|c|c|c|c|c|c|c|}
\hline \multirow{2}{*}{ Covariate } & \multirow{2}{*}{ Value } & \multicolumn{3}{|l|}{ Women } & \multicolumn{3}{|l|}{ Men } \\
\hline & & $\begin{array}{r}\text { Person- } \\
\text { years } \\
\end{array}$ & Events & $\begin{array}{r}\text { Prob. } \\
(\% o)\end{array}$ & $\begin{array}{r}\text { Person- } \\
\text { years } \\
\end{array}$ & Events & $\begin{array}{r}\text { Prob. } \\
(\% o) \\
\end{array}$ \\
\hline TOTAL & & 304618 & 993 & 3.26 & 319428 & 728 & 2.28 \\
\hline Marriage & 0 & 12109 & 20 & 1.65 & 13747 & 16 & 1.16 \\
\hline \multirow[t]{4}{*}{ duration in years } & $1-3$ & 35392 & 165 & 4.66 & 40866 & 140 & 3.43 \\
\hline & $4-9$ & 62021 & 385 & 6.21 & 73160 & 286 & 3.91 \\
\hline & $10-21$ & 106731 & 321 & 3.01 & 120588 & 219 & 1.82 \\
\hline & $22-34$ & 88365 & 102 & 1.15 & 71067 & 67 & 0.94 \\
\hline \multirow[t]{3}{*}{ Current age } & Less than 25 & 26632 & 155 & 5.82 & 17845 & 80 & 4.48 \\
\hline & $25-34$ & 96155 & 485 & 5.04 & 108509 & 380 & 3.50 \\
\hline & $35-54$ & 165176 & 294 & 1.78 & 193074 & 268 & 1.39 \\
\hline \multirow[t]{2}{*}{ Calendar year } & $1977-1981$ & 109225 & 206 & 1.89 & 110222 & 154 & 1.40 \\
\hline & $1982-1990$ & 195393 & 787 & 4.03 & 209206 & 574 & 2.74 \\
\hline Out-of-wedlock & No & 266654 & 855 & 3.21 & 276988 & 593 & 2.14 \\
\hline birth & Yes & 37964 & 138 & 3.64 & 42440 & 135 & 3.18 \\
\hline Age difference & -3 to 15 years & 295776 & 947 & 3.20 & 310163 & 700 & 2.26 \\
\hline between husb. \& wife & Other & 9470 & 48 & 5.07 & 9265 & 28 & 3.02 \\
\hline \multirow{4}{*}{$\begin{array}{l}\text { Size of place } \\
\text { of residence }\end{array}$} & $5000-$ & 49716 & 49 & 0.99 & 50700 & 62 & 1.22 \\
\hline & $5001-20000$ & 59122 & 149 & 2.52 & 64044 & 88 & 1.37 \\
\hline & $20001-100000$ & 68151 & 199 & 2.92 & 71580 & 158 & 2.21 \\
\hline & $100001+$ & 127629 & 596 & 4.67 & 133104 & 420 & 3.16 \\
\hline \multirow{4}{*}{$\begin{array}{l}\text { Family structure } \\
\text { (age of wife) }\end{array}$} & No children (40-) & 43707 & 212 & 4.85 & 48469 & 162 & 3.34 \\
\hline & 1 minor & 60591 & 341 & 5.63 & 69599 & 235 & 3.38 \\
\hline & $2+$ minor & 150450 & 380 & 2.53 & 164928 & 288 & 1.75 \\
\hline & Other situations & 49870 & 60 & 1.20 & 36432 & 43 & 1.18 \\
\hline \multirow{5}{*}{$\begin{array}{l}\text { Educational } \\
\text { level }\end{array}$} & No education & 30107 & 62 & 2.06 & 23623 & 32 & 1.35 \\
\hline & Less than primary & 62507 & 112 & 1.79 & 57618 & 70 & 1.21 \\
\hline & Primary & 161360 & 451 & 2.79 & 162970 & 330 & 2.02 \\
\hline & Secondary & 28924 & 208 & 7.19 & 46034 & 180 & 3.91 \\
\hline & Post-secondary & 21720 & 160 & 7.37 & 29183 & 116 & 3.97 \\
\hline \multirow{4}{*}{$\begin{array}{l}\text { Employment } \\
\text { status }\end{array}$} & Not employed & 201822 & 370 & 1.83 & - & - & - \\
\hline & Employed & 102796 & 623 & 6.06 & - & - & - \\
\hline & Not employed or unstable job & - & - & - & 17867 & 71 & 3.97 \\
\hline & In stable employment & - & - & - & 301561 & 657 & 2.18 \\
\hline
\end{tabular}




\begin{tabular}{|c|c|c|c|c|c|c|c|}
\hline Current & Prof. \& tech. & 17747 & 155 & 8.73 & 36146 & 121 & 3.35 \\
\hline \multirow[t]{6}{*}{ occupation } & Administrative service & 16763 & 150 & 8.95 & 32151 & 89 & 2.77 \\
\hline & Commerce & 13242 & 59 & 4.46 & 27412 & 72 & 2.63 \\
\hline & Pers. serv, hotel and catering & 24061 & 175 & 7.27 & 25352 & 83 & 3.27 \\
\hline & Farm work & 8491 & 4 & 0.47 & 27342 & 22 & 0.80 \\
\hline & Skilled workers & 11959 & 57 & 4.77 & 122001 & 220 & 1.80 \\
\hline & Unskilled workers & 10533 & 23 & 2.18 & 31157 & 50 & 1.60 \\
\hline \multirow{5}{*}{$\begin{array}{l}\text { Current } \\
\text { porfessional } \\
\text { situation }\end{array}$} & Family worker & 13424 & 7 & 0.52 & 21430 & 22 & 1.03 \\
\hline & Independent & 11229 & 44 & 3.92 & 48511 & 94 & 1.94 \\
\hline & Private firm & 52767 & 369 & 6.99 & 199961 & 454 & 2.27 \\
\hline & Public Administration & 17231 & 139 & 8.07 & 31659 & 87 & 2.75 \\
\hline & Domestic work & 8145 & 64 & 7.86 & - & - & - \\
\hline \multirow{13}{*}{$\begin{array}{l}\text { Current sector } \\
\text { of activity }\end{array}$} & Agriculture & 14887 & 11 & 0.74 & 38267 & 31 & 0.81 \\
\hline & Mines & - & - & - & 4513 & 13 & 2.88 \\
\hline & Industry \& construction & 20936 & 123 & 5.88 & 81033 & 144 & 1.78 \\
\hline & Construction & - & - & - & 42040 & 70 & 1.67 \\
\hline & Commerce & 17149 & 74 & 4.32 & 37908 & 89 & 2.35 \\
\hline & Hotel and catering & 6068 & 53 & 8.73 & 11928 & 48 & 4.02 \\
\hline & Trans. \& comm. & - & - & - & 24734 & 49 & 1.98 \\
\hline & Finance & - & - & - & 10063 & 31 & 3.08 \\
\hline & Public administration & 5188 & 39 & 7.52 & 19891 & 52 & 2.61 \\
\hline & Education & 10719 & 72 & 6.72 & 8824 & 33 & 3.74 \\
\hline & Health & 8201 & 76 & 9.27 & 5720 & 22 & 3.85 \\
\hline & Domestic Services & 8500 & 68 & 8.00 & - & - & - \\
\hline & Other services & 11148 & 107 & 9.60 & 16640 & 75 & 4.51 \\
\hline
\end{tabular}

Source: Own calculations from INE, Sociodemographic Survey, 1991 